\title{
Management of Innovative Development and Integrated Logistics System in the Russian Federation
}

\author{
Dmitry Morkovkin \\ Department of Macroeconomic Regulation \\ Financial University under Government of the Russian Federation \\ Moscow, Russia \\ E-mail: MorkovkinDE@mail.ru
}

\author{
Alla Nikonorova \\ Department of Management and Marketing \\ Moscow Witte University \\ Moscow, Russia \\ E-mail: nikonorova-av@mail.ru
}

\author{
Vitaliy Shumaev \\ Russian University of Transport \\ Center for Social and Economic Development of Regions \\ Moscow, Russia \\ E-mail: vitshumaev@mail.ru
}

\begin{abstract}
The article studies conceptual directions in innovative development management of logistics system in the Russian Federation. The economic position of the country is in direct dependence on the state of the transportation system. The specialized Federal target program "Integrated logistics system in the Russian Federation" is proposed to be developed as a means of innovative management improvement. Implementation of innovative technologies, expansion of integrated freight services, implementation of modern international technologies in logistics, creation of united integrated national logistics network, optimization of logistical operations, and improvement of the structure of the vehicle fleet and water transport, and other measures lead to the growth of the entire Russian economy.
\end{abstract}

Keywords-innovative development, management; logistics; transportation; infrastructure; program; logistics center

\section{INTRODUCTION}

For Russia, integration into the world economy has determined the direction to the global economic space with its financial, power supply, information, logistics, and other systems. Presently, Russia is facing the necessity of accessing the international logistics network with its developed infrastructure, institutional mechanisms, and informational subsystems.

Imposition of sanctions on the Russian Federation forced the government to consider domestic producers as main suppliers of provisions and industrial goods, but the aim of taking leading positions is not easy for them to be achieved due to the lack of appropriate infrastructure in the country. The quantity of stores, chillers, elevators, logistics centers, bases, and warehouses hasn't been enough so far. Thus, significant investments into construction of these facilities are required. But investments should be preceded with development of competent innovative projects considering proximity to customers, volume of storage places, processing, and transportation. This complex task should be settled at the level of the State. As a result, the development of integrated logistics system covering the territory of all the country is required.

\section{DEVELOPMENT OF THE "INTEGRATED LOGISTICS SYSTEM IN THE RUSSIAN FEDERATION” PROGRAM}

It is reasonable to form the innovative market infrastructure on the basis of a specialized Federal target program. Its development and implementation can increase efficiency of management. It is proposed in this paper to develop the program "Integrated Logistics System in the Russian Federation".

Achieving economic growth can only be possible through creating the right conditions for unlocking the nation's existing potential [1]. The fact is that spontaneous, uncoordinated creation of infrastructure's fragments that function in "their own way" in each region, district, or sector, and ignore international technical standards and organizational practice leads not only to numbness of major investments but also to aggravation of economic structures isolation both at local, regional, and world level. It limits economic opportunities for Russian entrepreneurs, weakening the economic security of Russia [2].

Implementation of innovative international technologies in logistics allows any region and the whole country obtaining the following consequences:

1. Improvement of goods transportation through supply chains. Reduction of costs, which can be achieved owing to:

- Ensuring loop termination of the cycle "extraction of feedstock - purchase - processing - production - sale of finished commodity".

- Significant reduction of expenditures in the structure of products price, which are connected with transport, 
loading and unloading, transshipment, dispatching, customs, and security costs.

- Reduction in number of unnecessary intermediaries and deadheading, improvement of cargoes security, online tracking, and control of precise cargoes location and their condition.

2. Attraction of domestic and foreign flows of cargoes and capital with infrastructural readiness; the growth in financial turnover and tax collections in the regions; growth in regional economy development owing to consolidated efforts of big and small-scale business.

3. Optimization of logistical operations at industrial enterprises, usage of computer integrated manufacturing (CIM). Creation of new production capacities and jobsites in following sectors: processing of local raw materials resources, wood processing, construction and civil engineering infrastructure, transportation, engineering and instrument making industry, communications, light industry and consumer service; agriculture and food industry, market infrastructure (packing and processing for wholesale or retail sale), business service.

4. Development of rational layouts for cities, settlements, and productive forces (the development of city logistics); development of modern social and business infrastructure (housing, communication, transportation, retail, recreation, catering, and service).

5. Improvement of ecological state of territories by removing heavy and dangerous cargoes outside cities, partial transportation of goods by river and rail transport, dispersion of petrochemical terminals, and wide usage of sealed containers. Oil and oily residue discharges from ships, offshore platforms, and oil terminals represent a significant threat to marine ecosystems [3]. Usage of scientific researches data are able to facilitate the discrimination between different types of surface pollutants, to reveal the meteorological and hydrodynamic processes in test areas, and to determine factors governing pollutants spread and drift [4]. Thus, negative impacts on the marine environment can be reduced with implementation of advanced technologies worked out in accordance with the results of scientific researches.

It's necessary to emphasize that the improvement of separate fragments in the logistic system does not lead to the desired effect and cannot be considered as the ultimate task for distribution optimization. Only loop combining such steps as "development of local resources" - "procurement" "manufacturing" - "warehousing" - "transportation" "sales" forms a complete self-sustaining synergetic cycle and produces the effect.

The socioeconomic effect from the implementation of integrated logistics system in the Russian economy cannot be precisely estimated. It can be compared to the effect of such phenomenon of scientific and technological progress as electrification, industrialization, chemicalization, and computerization of the national economy. Logistics networks can be compared to power networks or to the Internet, however, while in the two previous cases energy and information are the objects to be transmitted, logistics manage material flows.

In the future, the entire complex of logistics infrastructure is to form a united and integrated national logistics network. Coordination of the work of regional logistics infrastructure and lading transportation across the territory of the country should be managed by the Federal logistics control center.

Special role in logistics belongs to transport, which is engaged in physical transference of passengers and goods.

Transportation through the territory of the Russian Federation is able to unite the countries of Europe, Asia, the Caucasus, the Middle East, Central Asia, India, China, Korea, and Japan. It's very attractive and suitable for allocation of global capital and development of commodity production. Russia is located between European and Asian countries, and, owing to international transport, corridors can facilitate trade, economic, scientific, and cultural exchange between different states and peoples. Transport communications form the basis of foreign economic relations. They create the necessary prerequisites for integration of Russia into the global economy.

The economic position of the country is in the direct dependence on the functioning and development of the transportation system [5]. The development of innovative transportation infrastructure and its adjacent territories should be aimed at forming the common free market zone in the country. It helps to solve world economic problems at the level of the country and its regions.

The export-import operations, including cargoes transportation between Asia and Europe and from South to North and back, have been still limited because of low capacity of harbor installations, which is to be increased.

The dynamics of export operations in the period of 20002016 is shown in "Table I" [6].

TABLE I. EXPORTS OF THE RUSSIAN FEDERATION (MLN. US DOLLARS)

\begin{tabular}{|c|l|l|l|l|l|}
\hline Exports & 2000 & 2010 & 2014 & 2015 & 2016 \\
\hline Total & 103093 & 397068 & 497359 & 343512 & 285674 \\
\hline including: & & & & & \\
\hline $\begin{array}{c}\text { with the CIS } \\
\text { countries }\end{array}$ & 13824 & 59601 & 64186 & 45092 & 37730 \\
\hline $\begin{array}{c}\text { with far abroad } \\
\text { countries }\end{array}$ & 89269 & 337467 & 433173 & 298420 & 247944 \\
\hline
\end{tabular}

As far as the dynamics of import operations in 2000-2016 is concerned, it can be seen in the "Table II" [6].

TABLE II. IMPORTS OF THE RUSSIAN FEDERATION (MLN. US DOLLARS)

\begin{tabular}{|c|l|l|l|l|l|}
\hline Imports & 2000 & 2010 & 2014 & 2015 & 2016 \\
\hline Total & 33880 & 228912 & 287063 & 182902 & 182267 \\
\hline including: & & & & & \\
\hline $\begin{array}{c}\text { with the CIS } \\
\text { countries }\end{array}$ & 11604 & 31728 & 33287 & 21210 & 19543 \\
\hline $\begin{array}{c}\text { with far abroad } \\
\text { countries }\end{array}$ & 22276 & 197184 & 253776 & 161693 & 162725 \\
\hline
\end{tabular}


The volume of foreign trade turnover had been alternated within the period of 2000-2016. On the basis of the analysis of the data above the following conclusion can be done.

The comparison of the data of the "Table I" and "Table II" shows that the volume of exports operations significantly exceeds the volume of imports operations. Therefore, the infrastructure in the Russian Federation should completely correlate with foreign logistics networks. Implementation of innovative technologies in logistics and transportation system creates the necessary prerequisites for steady development of foreign trading. That is why the role of coordinating cargo transportation processes through the territory of the country is topical.

The North Sea route may become another Eurasian transit to link the countries of the European Union and the Asia-Pacific region, besides in the long-term perspective the Russian part of the Arctic will richly provide not only Russia but the whole planet with mineral resources.

The high-tech Euro-Asian transport system is able to unite all modes of transport and international transport corridors. Integral hubs with a single dispatcher control systems, transport and logistics centers, universal automated terminal and warehouse complexes located in the immediate vicinity of commodity exchanges and wholesale markets are to integrate rail, road, and air transport [7].

The regions are interested in development of transport system, as its implementation will be able to solve the most significant problems of communications, construction of industrial and civil objects. Successful management of infrastructure development is a result of the work of skilled personnel and is connected with development of higher, secondary and special education.

Implementation of integrated and coordinated state policy in the field of transport services, industrial development areas, intersectoral communications, and providing infrastructure is one of the most significant tasks in management. First of all, political decisions concerning transportation system development as the basis of economic growth is required. Its implementation requires development of project management mechanisms that will ensure combination of federal, regional, and sectoral interests. Having unique opportunities in processes coordination the state should become the initiator of business offers. It is also reasonable to create several international consortia for development and implementation of joint projects. Thus, a qualitatively new system of state and municipal management should be formed.

The special role in development of transportation system belongs to improvement of technical level of vehicles and equipment, usage of modern transport, management, and information technologies. The transport system should be focused on the usage of domestic transport machinery and equipment. Transportation of passengers and cargoes through the territory of the Russian Federation should be made by domestic carriers. Administrative measures are able to establish an order, which would help to prepare Russian transport carriers and forwarding services to work with foreign clients.

Taking into consideration sanctions of the Western partners, it is reasonable to focus on the production and use of domestic equipment. This activity should be supported by the state. However, it should not create obstacles in import of modern transport technology that has not been produced in the Russian Federation.

To change the structure of the vehicle fleet and water transport it is reasonable [7]:

- As to railway transport: to increase quantity of modern high-efficient freight locomotives, freight cars with excess carrying capacity and reliability; to increase share of high-speed passenger rolling stock; to expand fleet of more comfortable passenger cars, suburban and interregional trains.

- As to sea transport: to construct large-capacity vessels of "Baltmax" and "Bosporusmax" series in order to ensure export growth of oil; to construct specialized gas tankers for export activity in Yamal, Sakhalin and other gas fields; to construct modern ferries; to construct modern icebreakers to provide transportation in the Arctic shelf.

- As to river transport: to create new, economical types of boats, boats for operation in shallow areas; to increase usage of heavy-load barges; to create a new generation of comfortable river boats.

- As to motor transport: to increase quantity of high carrying capacity lorries, to expand the range of specialized semitrailers to meet growing demand for intercity and international transportation; to increase number of specialized truck chassis, including ones equipped with self-loading systems and range of interchangeable car bodies to serve retail trade, small business, farms, public utilities.

- As to air transport: to create and launch new family of economical aircraft.

Choosing the mode of cargo transportation in ordinary practice it is necessary to make thorough cost estimates that would help to minimize total costs of ownership (TCO) for each vehicle system. As it was shown in recent studies, total costs of ownership consist of three main components: purchase price $(\mathrm{P})$, residual value $(\mathrm{V})$, and cost operation $(\mathrm{C})$ [8].

$T C O_{\text {vehicletype }}=\frac{\text { Pvehicle }- \text { Vresidual }}{\text { yearsservice }}+C_{\text {operation }}$

The complex consideration of all opportunities and expenses would assist in choosing the most efficient mode.

\section{IMPROVEMENT IN MANAGEMENT TRANSPORT AND TECHNOLOGICAL INFRASTRUCTURE}

One of the main progressive directions of improvement in transport technologies in the field of freight transportation is integration of industrial and transport processes on the 
basis of logistical principles. Improvement in management transport and technological infrastructure is to be carried out in the following main directions:

- Construction of roads and railways; conducting fiber optics communication lines.

- Reconstruction of existing roads and railways in accordance with new requirements.

- Improvement of regional transport infrastructure covering areas of mining in North and Eastern Asia, as well as areas of national projects development.

- Increase in seaports capacity and specialization to conform growing volume of foreign cargoes (grain, coal, charge stock in containers), usage of Russian ports instead of foreign ones for foreign trade.

- Formation of hub distribution centers network for air transportation (hereinafter - hub airports), construction of new cargo and passenger terminal facilities, reconstruction of runways.

- Capacity of existing and creation of additional terminal facilities, including container terminals.

- Further development of logistics and information technologies, the entire infrastructure of transportation in order to assure guaranteed delivery of goods, improve quality of service, ensure their safety.

- Modernization of border check-points facilities, improvement of customs inspection and customs clearance procedures, bringing them in compliance with international practice.

- Implementation of modern technologies of electronic logistic support for customs clearance and control of goods and vehicles.

Efficient functioning of routes requires creation of multifunctional local roadside service centers that can be located in a city, suburb, or outside residential areas and include catering trade, hotels, medical care services, consumer services, car rental firms, service centers, communication services, and etc. It is also necessary to provide staff with housing and to create appropriate infrastructure. This activity will be a part of neighboring territories and regions development project [9]. The functions of regulating these processes shift from central to regional authorities. In the conditions of the transitional economy, the role of the process of attracting and distributing financial resources in regulating reproduction processes is strengthened, and the whole system of financial relations is being activated [10].

Construction of traffic routes and integrated logistics junctions will cause the necessity and opportunity for development of industry, agriculture, construction, and services sectors. In particular it will cause:

- Development of hydropower engineering, nuclearpower and fuel engineering, construction of renewable energy power stations, receiving energy of such sources as wind, solar, wave, and etc.

- Increase in oil and gas production; deepen gas and oil refining.

- Wide use of modern technologies in mechanical engineering; import substitution; development and manufacture of modern high-speed vehicles.

- Increase of refined substances export.

- Rational use of forest resources used in production cycles; reforestation.

- Increase in production of coking coal, ores; development of metallurgy in Siberia, the Far East, the North of the European part of Russia.

- Growth in building engineering, production of construction materials.

- Creation of modern live stocks to satisfy both Russian market and export needs; increase in harvest of agricultural products; improvement of infrastructure, increase in number and amounts of storages and products processing [11].

Therefore, creation of high-tech Euro-Asian transport system may become a crucial project for innovative economy development in such fields as industry, construction, and transport can lead to socio-economic development of regions.

Inland water transport plays a special role in Russia due to her largest rivers in Eurasia and around the world. In conditions of a market economy, inclusion of the world's longest inland water-ways and involvement of effective domestic fleet that is able to navigate both through seas and rivers can give such additional advantages as:

- Direct transportation from a river dock of a Russian consignor to a foreign internal port or even directly to a dock of a consignee.

- Usage of powerful transport facilities: volume of one medium-sized "Sea-river" vessel is equal to a railway line, while its fuel and oil consumption is significantly lower.

- Water transport is much friendlier to environment in comparison with road and rail transportation.

- Opportunity to supply remote and hard-to-reach areas, especially during spring tide.

- Development of industrial and city-forming potential in places of explored mineral deposits and forests, which are located in river basins.

- Elaboration of water-based recreation and boating as attractive and profitable business activity.

- Development of interregional and international economic relations leading to efficient usage of railway communications. 
- Attraction of investments and ensuring of work and development of other modes of transport (railway, motor transport), as well as of processing capacities (cargo and sorting junctions, ports, terminals, distribution centers, warehouses, and etc.), and industrial enterprises.

It should be noted that water transport has a priority in the national economic policy. It attracts public and private investments to the countries with a large number of rivers. The Russian national transport system cannot be considered as adequate without active usage of inland waterways and powerful "Sea-river" vessels fleet.

The above-mentioned confirms necessity to apply comprehensive approach to making arrangements for integration of Russian transportation management and warehousing into the global standardized logistics system, maximum receptivity of positive foreign experience in this sphere.

\section{CONCLUSION}

Taking into consideration modern conditions, it is proposed to develop the Federal target program "Integrated Logistics System in the Russian Federation until 2030" that is to determine the directions for management of logistics infrastructure comprehensive development. It should be applied to the entire territory of the country, and its measures should be oriented toward the foreseen development of discovered deposits, industrial and agricultural areas, transport routes, attending productions, service centers, and social infrastructure. It is recommended to stipulate in the program the creation of the Federal logistics headquarters that would carry out the common policy in distribution system and coordinate activity of all logistics centers both at the federal and regional level. The integrated logistics system in Russia should include international shipments center, coordinating transportation through international transport corridors and usage of appropriate infrastructure. It is also reasonable to devote special section of the program to development and functioning of the Northern sea route and adjacent territories. The implementation of this program not only will protect Russia from crises, but it also will stimulate development of energy sector, industry, agriculture, will have positive influence upon the economy of the whole country.

\section{REFERENCES}

[1] M.Ya. Veselovsky, A.V. Nikonorova, A.A. Stepanov, N.L. Krasyukova, I.V. Bitkina, The development of innovative startups in Russia: the regional aspect // Academy of Strategic Management Journal, 2017. 16, № 1, pp. 197-208.

[2] V.N. Alenkov, V.N. Mironov, V. N., and V.A. Shumaev, Complex trade and transport logistics network: infrastructure development in the conditions of Russia's accession to the WTO // Rules of Play, 2003, No. 1, pp. 27 - 33.

[3] A.G. Kostianoy, E.V. Bulycheva, A.V. Semenov, and A. Krainyukov, Satellite monitoring systems for shipping and offshore oil and gas industry in the Baltic Sea // Transport and Telecommunication, 2015. No. 16(2), pp. 117-126. DOI:10.1515/ttj-2015-0011
[4] O.Yu. Lavrova, M.I. Mityagina, A.G. Kostianoy, and A.V. Semenov, Oil pollution in the Southeastern Baltic Sea in 2009-2011 // Transport and Telecommunication, 2014. No. 15(4), pp. 322-331. DOI:10.2478/ttj-2014-0029

[5] A. Brikin and V. Shumaev, The contours of the high-tech transport system // Economist, 2010. No. 11, pp. 37-43

[6] Federal State Statistics Service of the Russian Federation. Russian statistical yearbook. Statistical handbook (2017) Rosstat. Retrieved January 08, 2018, from http://www.gks.ru/free_doc/doc_2017/year/year17.pdf

[7] V.A. Shumaev and V.N. Mironov, Foreign experience of management: development of logistics infrastructure and export potential on the basis of organization of free economic zones. Management and business administration (MBA), 2011. No. 3, pp. 78-92.

[8] Graurs, A. Vizulis, A. Rubenis, and A. Laizāns. Wireless energy supply to public transport units with hybrid drive - trends and challenges // Transport and Telecommunication, 2014, No. 15(1), pp. 67-76, DOI:10.2478/ttj-2014-0007

[9] D.E. Zakharov, A.A. Lobanov, and V.A. Shumaev, Development of infrastructure as a factor of enhancing innovative activity and crisis overcoming. Resources, Information, Supply, Competition (RISK), 2009. No. 2, pp. 113-117.

[10] D.S. Reznichenko, E.S. Tishchenko, I.V. Taranova, M.V. Charaeva, A.V. Nikonorova, E.R. Shaybakova, Sources of Formation and Directions of the Use of Financial Resources in the Region // International Journal of Applied Business and Economic Research, 2017. № 15 (23), pp. 203-219.

[11] A. Nikonorova, D. Morkovkin, N. Isaichykova, V. Nezamaikin. Improvement of Innovative Infrastructure as a Means of Economic Development // Advances in Economics, Business and Management Research, 3rd International Conference on Economics, Management, Law and Education (EMLE 2017), vol. 32, Atlantis Press, 2017. pp. 1-4. URL: http://creativecommons.org/licenses/by-nc/4.0/ 